6. Mukan N. V. Systema neperervnoi profesiinoi osvity pedahohiv Kanady: instytutsii ta yikhnia diialnist. Visnyk Lvivskoho universytetu. Seriia : «Pedahohichna». 2007. Vyp. 22. S. 227-231.

7. Pryshliak O. Yu. Profesiinyi rozvytok pedahohiv u SShA i FRN. Naukovyi visnyk Uzhhorodskoho natsionalnoho universytetu. Seriia : «Pedahohika, sotsialna robota». 2012. Vyp. 27. S. 159-162.

8. Semenets-Orlova I. A. Velykobrytaniia: novi vchyteli dlia novoho suspilstva. URL: http://education-ua.org/ua/porivnyalnapedagogika/460-velikobritaniya-novi-vchiteli-dlya-novogo-suspilstva (data zvernennia: 23.05.2017).

9. Evaluating CPD: an Overview / Muijs D. \& other. International Handbook on the Continuing Professional Development of Teachers / ed. by C. Day, J. Sachs. Glasgow : Open University Press, 2004.

10. Glatthorn A. Teacher development. International Encyclopedia of teaching and teacher education. 2nd edition. London : Corwin Press, 1995.

11. Lowry C., \& Froese W. Transitions: Becoming a college teacher. 2001 PanCanadian Education Research Agenda Symposium. Teacher education. Educator training: current trends and future directions, 22-23, May, 2001.

\title{
Martynets L. A. To the issue of professional development of teachers of UK, Canada and USA
}

The article reveals the system of professional development of teachers in the UK, Canada and USA. It is highlighted that the success indicators of professional development of teachers of the UK are growing significantly. The state increases the allocation for the professional development of teachers. In general, being the best in education in the UK is rewarding. Continuous education of teachers in the UK is aimed at developing an individual strategy and teaching style of teachers capable of professional development, which is provided not only by scientific grounding (defining goals, shaping and structuring content corresponding to the goals), but also by careful technological processing.

It is noted that in Canada, special attention is paid to ensuring the continuing professional development of educators who work in the continuous vocational education system and guide their activities to the professional development of teachers in Canada's comprehensive schools. The activity of the system of continuous vocational education is aimed at providing opportunities for professional development, obtaining of a new qualification or specialty, as well as a profession based on the previously acquired level of educational and vocational training, gained practical experience.

The analysis of continuous professional development of teachers in the United States reveals a considerable variety of approaches, forms and methods to postgraduate teacher training. The increase of professional pedagogical networks in the United States demonstrates the openness of the circulatory system and the dissemination of knowledge in practical pedagogical activities. It is determined that it makes the system of knowledge transfer between teachers more flexible and effective-communication increases the motivation of teachers and self-education.

Key words: professional development, teacher, advanced training, institutions, forms of professional development, teachers' association, federation of teachers, continuous vocational pedagogical education.

УДК 378.22:378.091.12:001.89

DOI https://doi.org/10.31392/2311-5491/2019-69.30

Меняйло В. I.

\section{ТЕОРЕТИЧНІ ТА ПРАКТИЧНІ АСПЕКТИ \\ КАДРОВОГО ЗАБЕЗПЕЧЕННЯ ПРОЦЕСУ ПІДГОТОВКИ МАЙБУТНІХ ДОКТОРІВ ФІЛОСОФІї ДО ДОСЛІДНИЦЬКО-ІННОВАЦІЙНОї ДІЯЛЬНОСТІ}

У роботі висвітлено теоретичні підходи та практичний досвід Запорізького національного університету щзодо кадрового забезпечення процесу підготовки майбутніх докторів філософії до дослідницько-інноваційної діяльності. Вирімення иього питання розглядається у трьох аспектах: призначення наукових керівників аспірантів, відбір науково-педагогічних прачівників для викладання дисичилін, орієнтованих на формування готовності до дослідницько-інноваційної діяльності, а також запровадження неформального інституту менторів на першому році навчання в аспірантурі. Сформульовані вимоги до наукових керівників аспірантів, серед яких: вільне володіння сучасним станом досліджень в обраній галузі науки, вагомі наукові здобутки, організаційні та людські якості, знання іноземної мови, наукова репутація, приналежність до визнаної наукової школи. Основними критеріями відбору викладачів є максимальна відповідність професійного досвіду та результатів професійної діяльності змісту курсів, щчо пропонуються освітньою складовою (иього можна досягти розбивкою дисииплін на модулі, кожний з яких забезпечує окремий викладач, найбільш наближений до тематики модуля), володіння сучасними педагогічними технологіями та відповідними педагогічними якостями. До викладання курсів можуть залучатися працівники інших закладів вищої освіти та професіонали-практики. Для підтримки аспірантів-початківців пропонується запровадити інститут менторів як дієвий механізм професійного становлення молодих науковиів. Показано, щуо функиії менторів можуть здійснювати викладачі, які забезпечують викладання дисииплін досліднищько-інноваційного спрямування на першому рочі навчання в аспірантурі шляхом надання індивідуальних консультацій як очних, так i дистаниійних за допомогою сучасних засобів комунікації. Головною вимогою до менторів є наявність власної історії професійного успіху у науковій сфері та бажання поділитися ним із своїми молодшими колегами.

Ключові слова: доктор філософії, науковий керівник, аспірант, дослідницько-інноваційна діяльність, ментор.

Однією з особливостей процесу формування готовності майбутніх докторів філософії до дослідницькоінноваційної діяльності є той факт, що він здійснюється докторами і кандидатами наук (докторами філософіi). Тому величезного значення для професійного становлення і розвитку аспірантів набуває особистий 
приклад наукових, науково-педагогічних працівників, залучених до підготовки наукових кадрів, як представників відповідного професійного середовища, частиною якого стануть і майбутні фахівці вищої кваліфікації.

Проведений аналіз нормативно-правової бази щодо підготовки докторів філософії свідчить про те, що законодавець в основному зосереджується на вимогах до здобувачів вищої освіти та інституцій, в яких здійснюється підготовка та атестація наукових кадрів, проте, майже не висуває ніяких нормативних вимог до наукових керівників, крім наявності наукового ступеня. Майже відсутні роботи щодо висвітлення питань відбору професійних кадрів для підготовки докторів філософії і у вітчизняній науковій літературі, окрім роботи О. Спіріна, де він рекомендує активніше залучати до цього процесу провідних вчених [10, с. 229 ] та О. Ярошенко, яка пропонує утвердити інститут наставництва з боку викладачів і вчених установ щодо науково-дослідницької діяльності здобувачів вищої освіти [13, с. 25$]$.

Метою статті $є$ розкриття теоретичних і практичних аспектів кадрового забезпечення процесу підготовки майбутніх докторів філософії до дослідницько-інноваційної діяльності на прикладі Запорізького національного університету.

Відповідно до Порядку підготовки здобувачів вищої освіти ступеня доктора філософії та доктора наук у закладах вищої освіти (наукових установах) одночасно із зарахуванням аспіранта йому призначається науковий керівник з числа наукових або науково-педагогічних працівників 3 науковим ступенем доктора або кандидата наук (доктора філософії), який здійснює наукове керівництво роботою над дисертацією, надає консультації щодо змісту і методології наукових досліджень аспіранта, контролює виконання індивідуального плану наукової роботи та індивідуального навчального плану аспіранта і відповідає перед вченою радою закладу вищої освіти за належне та своєчасне виконання обов'язків наукового керівника [8].

Як показують зарубіжні дослідження, якість наукового керівництва, у тому числі характер міжособистісних відносин 3 науковим керівником, суттєво впливає на ефективність роботи аспіранта. Російськими вченими було проведено опитування серед кандидатів наук щодо рівня впливу наукового керівництва на підготовку і захист їхнього дисертаційного дослідження, яке показало, що понад 70 \% опитаних оцінюють роль наукового керівника в успішному захисті їх дисертації у відсотковому вимірі як 50 \% і вище [12, с. 220]. Результати аналогічного експерименту представлено і бельгійськими дослідниками, які встановили, що визначальним фактором успішного завершення навчання в аспірантурі було справедливе ставлення до респондентів і визнання з боку наукових керівників [5, с. 115].

Як зазначає I. Котляров, взаємовідносини між аспірантом і науковим керівником слід розглядати у трьох площинах: як безпосереднє наукове керівництво дисертаційною роботою (вибір теми, методів дослідження, складання плану роботи тощо), організаційне керівництво діяльністю аспіранта (виконання індивідуального навчального і наукового планів, проходження атестацій, наявність необхідної кількості публікацій, вибір спеціалізованої вченої ради) і етичне керівництво (прищеплення аспіранту основ наукової етики) [6, с. 102]. Зважаючи на вищезазначене, ним були сформульовані основні вимоги до наукових керівників аспірантів [6, с. 103], які після деяких уточнень і доповнень покладені нами в основу критеріїв відбору наукових керівників для здобувачів наукового ступеня доктора філософії у Запорізькому національному університеті, серед яких:

1) володіння сучасним станом наукових досліджень у своїй предметній області, необхідне для вибору актуальної теми дисертаційного дослідження та його наукового супроводження на високому професійному рівні;

2) наявність вагомих наукових здобутків, підтверджених публікаціями у провідних вітчизняних та зарубіжних виданнях, насамперед тих, що входять до міжнародних наукометричних баз даних, отриманими грантами, укладеними договорами із замовниками тощо;

3) знання англійської мови в обсязі, достатньому для ознайомлення із зарубіжною науковою літературою, представлення своїх наукових результатів світовій спільноті та спілкування з іноземними партнерами;

4) організаційні якості, необхідні для ефективного керівництва процесом підготовки дисертаційної роботи, починаючи від затвердження теми і завершуючи захистом дисертації;

5) наукова репутація (авторитет у професійному середовищі, дотримання принципів академічної доброчесності, поважне ставлення до студентів та аспірантів, гідні людські якості).

Запорізький національний університет володіє наразі потужним науковим потенціалом: у ньому працює 746 штатних науково-педагогічних працівників, з них 124 докторів, професорів і 517 кандидатів наук, доцентів. Отже, відсоток НПП, що мають науковий ступінь, становить 86 \%. Серед науковців ЗНУ є багато визнаних в Україні та за кордоном вчених, які створили потужні наукові школи, в яких проходить підготовку більшість аспірантів ЗНУ.

Як зазначає О. Ярошенко, історія науки свідчить про те, що багато науковців стали всесвітньо відомими завдяки тому, що у свій час пройшли наукову школу видатного вченого; тому цей історичний досвід слід узяти на озброєння і у сучасних умовах підготовки здобувачів вищої освіти [13, с. 17].

Реєстр зазначених наукових шкіл, сформований на підставі розробленого і затвердженого Положення про наукові школи Запорізького національного університету [7], на сьогодні включає 18 наукових шкіл, що охоплюють усі напрями, за якими ведеться підготовка висококваліфікованих кадрів у ЗНУ.

У межах розробленої нами системи підготовки майбутніх докторів філософії до дослідницько-інноваційної діяльності велика увага приділяється не лише якісному відбору наукових керівників аспірантів, але 
й формуванню потужного викладацького складу для належного забезпечення освітньої складової процесу підготовки майбутніх докторів філософії. 3 метою отримання високих результатів навчання для викладання кожної дисципліни обираються найкращі науково-педагогічні працівники, які є найбільш компетентними у даній області, а також володіють сучасними педагогічними технологіями. Також не менш важливим фактором відбору $є$ і наявність у них таких професійно-значущих особистісних якостей як досвід педагогічного спілкування, педагогічного такту, педагогічного цілепокладання, педагогічного мислення [8, с. 46].

Нами застосовується практика, коли з однієї дисципліни призначаються по декілька викладачів, які забезпечують викладання окремих модулів, зміст яких корелює з професійними інтересами і практичним досвідом обраних педагогів-науковців. До членів викладацької команди, крім працівників ЗНУ, залучаються і представники інших закладів вищої освіти, і професіонали-практики. Наприклад, модуль «Риторика і практика публічних виступів» в університеті викладає відома журналістка, ведуча авторської програми на каналі «Запоріжжя: UA», голова редакційної ради Національної суспільної телерадіокомпанії України.

Третьою важливою складовою кадрового забезпечення підготовки докторів філософії до дослідницькоінноваційної діяльності є запровадження інституту наставників.

Як зазначає автор роботи [11, с. 45], до 90-х років XX століття у вітчизняному освітньому просторі існувала налагоджена система наставництва, орієнтована більше на виробництво і трудове виховання, ніж на задоволення особистісних потреб здобувачів вищої освіти.

Завдяки запровадженню особистісно-орієнтованого підходу це питання знов стало актуальним у вітчизняній педагогіці і йому приділяється достатньо уваги з огляду на позитивний досвід західної системи освіти. У зарубіжній педагогіці давно визнано, що наставництво або менторство чи менторинг (aнгл. Mentoring) $є$ важливим чинником у становленні дослідницької кар'єри майбутнього науковця [4]. Про різні моделі менторства можна довідатися із дослідження, проведеного британськими вченими [3], а 3 деякими практичними механізмами постійної підтримки здобувачів вищої освіти з боку менторів - ознайомитися з іноземних публікацій $[1 ; 2]$.

Під менторством у системі освіті зазвичай розуміють спеціально організовані особисті стосунки між досвідченим фахівцем і студентом-початківцем, які дають змогу останньому розвиватися професійно, академічно та особистісно [9]. У нашій практиці ми дійшли висновку, що менторські функції найкращим чином здійснюють ті ж самі науково-педагогічні працівники, які забезпечують освітню складову 3 питань підготовки майбутніх докторів філософії до дослідницько-інноваційної діяльності. У Запорізькому національному університеті цю роль виконують викладачі модулів: «Дослідницько-інноваційна діяльність у сучасному університеті», «Дисертація як проєкт», «Механізми фінансування наукових досліджень в Україні», «Публікації у виданнях, включених до міжнародних наукометричних баз даних», що є складниками навчального курсу «Основи дослідницько-інноваційної діяльності», та модулів: «Теоретичні основи проєктної діяльності», «Програми СС із грантової підтримки академічної мобільності та проєктів в галузі освіти», «Програми СС із грантової підтримки проєктів в галузі науки», що входять до курсу «Основи європейської проєктної діяльності».

Цей вибір менторів був зумовлений тим, що зазначені працівники:

- професійно та повною мірою володіють тими питаннями, що турбують аспірантів на початковому етапі підготовки в аспірантурі як викладачі тих навчальних дисциплін, що вчать їх орієнтуватися у науковому світі;

- як досвідчені педагоги, встановили партнерські відносини з майбутніми докторами філософії одразу ж після їх вступу до аспірантури, оскільки є викладачами, що забезпечують освітній процес на першому році навчання;

- мають власну історію успіху і можуть виступати взірцем для своїх молодших колег як такі, що мають серйозні професійні досягнення, серед яких: досвід наукової, науково-педагогічної, науково-організаційної роботи у закладі вищої освіти; наявність наукових статей у виданнях, що включені до міжнародних наукометричних баз даних; досвід участі у міжнародних та вітчизняних освітніх та наукових проєктах; до того ж вони завершують роботу над докторськими дисертаціями, тому краще за інших розуміють нагальні проблеми аспірантів і можуть надати їм кваліфіковану професійну допомогу з будь-якого питання під час індивідуальних консультацій чи дистанційно засобами електронної пошти, за допомогою телефонного зв'язку або онлайн-сервісів.

Висновки. Основними складовими системи кадрового забезпечення процесу ефективної підготовки майбутніх докторів філософії до дослідницько-інноваційної діяльності є: професійний відбір наукових керівників, що є представниками потужних наукових шкіл, якісний викладацький склад та неформальний інститут менторів з числа найдосвідченіших науково-педагогічних працівників, які мають вагомі наукові здобутки та відповідні педагогічні якості.

\section{Використана література:}

1. Byars-Winston A., Gutierrez B., Topp S., Carnes M. Integrating Theory and Practice to Increase Scientific Workforce Diversity : A Framework for Career Development in Graduate Research Training. CBE-Life Sciences Education. 2011. Vol. 10. P. $357-367$.

2. David J. Kupfer, Schatzberg A., Dunn L., Schneider A., Moore T., DeRosier M. Career Development Institute with Enhanced Mentoring : A Revisit. Acad. Psychiatry. 2016. Issue 40 (3). P. 424-428. DOI: 10.1007/s40596-015-0362-5.17. 
3. Lord P., Atkinson M., Mitchell H. Mentoring And Coaching For Professionals : A Study Of The Research Evidence : Research conducted by the National Foundation for Educational Research Northern Office. National Foundation for Educational Research. 2008. URL: https://www.nfer.ac.uk/mentoring-and-coaching-for-professionals-a-study-of-the-research-evidence.

4. Pfund C., Pribbenow C., Branchaw J., Miller Lauffer S., Handelsman J. The merits of training mentors. Science. 2006. Vol. 311. P. 473-474.

5. Travaglianti F., Babic A., Hansez I. Relationships between employment quality and intention to quit: focus on PhD candidates as traditional workers. Studies in Continuing Education. 2018. Vol. 40. № 1. P. 115-131. DOI: 10.1080/0158037X.2017.1396448.

6. Котляров И. Д. Проблемы осуществления научного руководства соискателями ученой степени кандидата наук. Образование и наука. 2010. № 11 (79). С. 98-106.

7. Положення про наукові школи Запорізького національного університету. Запорізький національний університет. URL: https://www.znu.edu.ua/ukr/sci/1363.

8. Про затвердження Порядку підготовки здобувачів вищої освіти ступеня доктора філософії та доктора наук у вищих навчальних закладах (наукових установах) : Постанова Кабінету Міністрів України від 23 березня 2016 р. № 261. Законодавство України. URL: http://zakon5.rada.gov.ua/laws/show/261-2016-\%D0\%BF.

9. Соколова Е. И. Анализ терминологического ряда «коуч», «ментор», «тьютор», «фасилитатор», «эдвайзер» в контексте непрерывного образования. Непрерывное образование: XXI век. 2013. Вып. 4. DOI: 10.15393/j5.art.2013.2171.

10. Спірін О. М., Носенко Ю. Г., Яцишин А. В. Сучасні вимоги і зміст підготовки наукових кадрів вищої кваліфікації з інформаційно-комунікаційних технологій в освіті. Інформаційні технології і засоби навчання. 2016. Т. 56. № 6. С. $219-239$.

11. Фаляхов И. И. Диверсификация моделей наставничества: ментор, тьютор, коуч, фасилитатор и идентификация их готовности к осуществлению наставнической деятельности. Казанский педагогический журнал. 2016. № 2. С. 45-49.

12. Эрнштейн Л. Б. Результативность деятельности аспирантуры и необходимость разработки общей теории научного руководства. Педагогическое образование в России. 2011. № 4. С. 218-223.

13. Ярошенко О. Г. Освітнє середовище науково-дослідницької діяльності в університеті: сучасні виклики. Конщепція та методологія реалізаиії науково-дослідницької діяльності суб'єктів навчально-виховного проиесу університетів : монографія / авт.: О. І. Бульвінська, Н. О. Дівінська, Н. О. Дяченко, О. В. Жабенко, І. О. Линьова, Ю. А. Скиба, Г. П. Чорнойван, О. Г. Ярошенко; за ред. О. Г. Ярошенко. Київ : Інститут вищої освіти НАПН України, 2016. С. 6-26.

\section{References:}

1. Byars-Winston A., Gutierrez B., Topp S., Carnes M. Integrating Theory and Practice to Increase Scientific Workforce Diversity : A Framework for Career Development in Graduate Research Training. CBE_Life Sciences Education. 2011. Vol. 10. P. $357-367$.

2. David J. Kupfer, Schatzberg A., Dunn L., Schneider A., Moore T., DeRosier M. Career Development Institute with Enhanced Mentoring : A Revisit. Acad. Psychiatry. 2016. Issue 40 (3). P. 424-428. DOI: 10.1007/s40596-015-0362-5.17.

3. Lord P., Atkinson M., Mitchell H. Mentoring And Coaching For Professionals : A Study Of The Research Evidence : Research conducted by the National Foundation for Educational Research Northern Office. National Foundation for Educational Research. 2008. URL: https://www.nfer.ac.uk/mentoring-and-coaching-for-professionals-a-study-of-the-research-evidence.

4. Pfund C., Pribbenow C., Branchaw J., Miller Lauffer S., Handelsman J. The merits of training mentors. Science. 2006. Vol. 311. P. 473-474.

5. Travaglianti F., Babic A., Hansez I. Relationships between employment quality and intention to quit: focus on PhD candidates as traditional workers. Studies in Continuing Education. 2018. Vol. 40. № 1. P. 115-131. DOI: 10.1080/0158037X.2017.1396448.

6. Kotljarov I. D. Problemy osushhestvlenija nauchnogo rukovodstva soiskateljami uchenoj stepeni kandidata nauk [Problems of conducting scientific management by candidates of a scientific degree of the candidate of sciences]. Obrazovanie i nauka. 2010. № 11(79). P. 98-106 [in Russian].

7. Polozhennia pro naukovi shkoly Zaporizkoho natsionalnoho universytetu [Regulations on scientific schools of Zaporizhzhia National University]. Zaporizhzhia National University. URL: https://www.znu.edu.ua/ukr/sci/1363 [in Ukrainian].

8. Pro zatverdzhennia Poriadku pidhotovky zdobuvachiv vyshchoi osvity stupenia doktora filosofii ta doktora nauk u vyshchykh navchalnykh zakladakh (naukovykh ustanovakh) : Postanova Kabinetu Ministriv vid 23.03.16 r. № 261. [On Approval of the Procedure for Preparing Graduates of Higher Education for the Degree of Doctor of Philosophy and Doctor of Science in Higher Educational Institutions (Scientific Institutions) : Resolution of the Cabinet of Ministers of Ukraine. 23.03.16. № 261] Zakonodavstvo Ukrainy. URL: http://zakon5.rada.gov.ua/laws/show/261-2016-\%D0\%BF [in Ukrainian].

9. Sokolova E. I. Analiz terminologicheskogo rjada «kouch», «mentor», «t'jutor», «fasilitator», «jedvajzer» v kontekste nepreryvnogo obrazovanija [The analysis of terminological row «coach, mentor, tutor, facilitator, advisor» within the frame of lifelong learning]. Nepreryvnoe obrazovanie: XXI vek. 2013. No. 4. DOI: 10.15393/j5.art.2013.2171 [in Russian].

10. Spirin O. M., Nosenko Ju. Gh., Jacyshyn A. V. Suchasni vymoghy i zmist pidghotovky naukovykh kadriv vyshhoji kvalifikaciji $\mathrm{z}$ informacijno-komunikacijnykh tekhnologhij v osviti [Current Requirements and Contents of Training of Qualified Scientists on Information and Communication Technologies in Education]. Informacijni tekhnologhiji i zasoby navchannja. 2016. Vol. 56. No 6. P. 219-239 [in Ukrainian].

11. Faljahov I. I. Diversifikacija modelej nastavnichestva: mentor, t'jutor, kouch, fasilitator i identifikacija ih gotovnosti $\mathrm{k}$ osushhestvleniju nastavnicheskoj dejatel'nosti [The Diversification Of Mentoring Models : Mentor, Tutor, Coach, Facilitator And Their Readiness Identification to Implement Mentoring Activities]. Kazanskij pedagogicheskij zhurnal. 2016. No. 2. P. 45-49 [in Russian].

12. Jernshtejn L. B. Rezul'tativnost' dejatel'nosti aspirantury i neobhodimost' razrabotki obshhej teorii nauchnogo rukovodstva [Efficiency of Post-Graduate Education and the Necessity of Development of the General Theory of Scientific Management]. Pedagogicheskoe obrazovanie v Rossii. 2011. No. 4. P. 218-223 [in Russian].

13. Jaroshenko O. Gh. Osvitnje seredovyshhe naukovo-doslidnycjkoji dijaljnosti v universyteti: suchasni vyklyky [Educational environment of research at the university: current challenges]. Koncepcija ta metodologhija realizaciji naukovo-doslidnycjkoji dijaljnosti sub’jektiv navchaljno-vykhovnogho procesu universytetiv: monoghrafija / avt.: O. I. Buljvinsjka, N. O. Divinsjka, N. O. Djachenko, O. V. Zhabenko, I. O. Lynjova, Ju. A. Skyba, Gh. P. Chornojvan, O. Gh. Jaroshenko; za red. O. Gh. Jaroshenko. Kyiv.: Instytut vyshhoji osvity NAPN Ukrajiny. 2016. P. 6-26 [in Ukrainian]. 
Meniailo V. I. Theoretical and practical aspects of staffing of the process of preparation of the training of the future doctors of philosophy for research and innovation activity

The paper describes theoretical approaches and practical experience of the Zaporizhzhia National University of staffing of the training of the future PhD for research and innovation activity. The solution of this issue is considered in three aspects: appointment of scientific supervisors for graduate students, selection of academic staff for the teaching of disciplines focused on forming readiness for research and innovation activity, as well as the introduction of an informal institute of mentoring in the first year of postgraduate study. The article formulates the requirements for scientific supervisors for postgraduate students, including: fluency in the current state of research in the chosen field of science, significant scientific achievements, organizational qualities, knowledge of a foreign language, scientific reputation, affiliation to a recognized scientific school. The main criteria of selection of teachers is the maximum correspondence of professional experience and the results of the professional activity content to the courses offered by the educational component (this can be achieved by the division of disciplines into modules, each of which is provided by a separate teacher, most closely related to the subject of the module), the possession of modern pedagogical technologies and relevant pedagogical qualities. Professors of other institutions of higher education and practitioners may be involved in teaching courses. In order to support postgraduate students, it is proposed to introduce an institute of mentors as an effective mechanism for the professional formation of young scientists. It is shown that the functions of the mentors can be carried out by the teachers. These lecturers provide teaching of research and innovation disciplines in the first year of postgraduate training by providing individual consultations, both on-site and distance. The main requirement for mentors is the presence of their own history of professional success in the scientific sphere and the desire to share it with their younger colleagues.

Key words: Doctor of Philosophy, Scientific supervisor, PhD-student, Research and Innovation Activity, Mentor.

УДК 372.881.111.1

DOI https://doi.org/10.31392/2311-5491/2019-69.31

Михайлішина К. I.

\section{АНАЛІЗ ЕЛЕМЕНТІВ СУЧАСНОГО УРОКУ АНГЛІЙСЬКОЇ МОВИ ТА ЙОГО ОРГАНІЗАЦІЯ}

Пошук перспективно нових методик викладання англійської мови в середній і старшій школі в сучасному світі зумовлює постійну модернізацію та вдосконалення освітнього процесу. Сьогодні ми переважно спостерігаємо залежність від системи освіти минулого століття: наявні в українській школі способи викладання іноземної мови переважно застарілі. Проблема викладання іноземної мови у вітчизняній науково-педагогічній літературі висвітлена досить широко (Л. С. Панова, І. Ф. Андрійко та ін.), різні аспекти вивчення англійської мови проаналізовано в численних зарубіжних дослідженнях (А. Абрамс (A. Abrams), Л. Бахман (L. Bachman), М. Хоккет (M. Hockett) та ін.). Проте наукове осмислення й застосування сучасних зарубіжних методів навчання іноземних мов в школах Украӥни зустрічається лише в окремих наукових розвідках. Відповідно, існує потреба в оновленні програм з методики викладання іноземних мов в украӥнських навчальних закладах. Стаття присвячена аналізу елементів сучасного уроку англійської мови та способів упровадження ичи елементів у навчальний процес. Розкрито мету й завдання основних принцииів та етапів сучасного уроку з англійською мови. На основі спостереження під час практики й аналізу результатів анкетування учнів напередодні та після введення зазначених методів у навчальний проиес охарактеризовано ефективність запроваджених методик (на прикладі групи учнів онлайн-школи англійської мови Skyeng). Визначено недоліки в організації та проведенні уроків з іноземної мови в школах, окреслено шляхи підвищення ефективності занять. Дослідження може зацікавити методистів $і$ вчителів іноземної мови. Основні положення, рекомендації та висновки, викладені в дослідженні, можуть бути використані в навчальному процесі, а також розширити, змінити методику викладання іноземної мови.

Ключові слова: англійська мова, методи навчання, технології, лексика, граматика, читання, аудіювання, тайм-менеджмент.

Пошук перспективно нових методик викладання англійської мови в середній і старшій школі в сучасному світі зумовлює постійну модернізацію й удосконалення освітнього процесу. Проблема підвищення якості, осучаснення навчання набуває ще більшого значення, оскільки спосіб навчання в українській школі сьогодні не мотивує дітей до навчання, учителі використовують переважно застарілі дидактичні засоби. Тобто сьогодні ми переважно спостерігаємо залежність від системи освіти минулого століття.

Відповідно до Концепції «Нової української школи» та проекту Концепції розвитку освіти України на період 2015-2025 років, модернізація освіти загалом і зокрема сучасного викладання англійської мови має сприяти вихованню таких якостей у випускника Нової української школи, як не тільки здатність сприймати й розуміти іноземну мову (далі - IM), а й бути готовим швидко адаптуватися до сучасного міжкультурного простору й активно взаємодіяти в ньому, конкурувати на ринку праці, учитися впродовж життя [1].

В. Загвязинський у працях відзначав: «Нове в педагогіці - це не лише ідеї, підходи, методи, технології, які в таких поєднаннях ще не висувалися або ще не використовувалися, а й той комплекс елементів чи окремі елементи педагогічного процесу, які мають у собі прогресивне начало, що дає змогу під час зміни умов і ситуацій ефективно вирішувати завдання виховання та освіти» [2, с. 23]. 